\title{
Stagnation in Terrorism Research: A Critical Overview on Bangladesh
}

\author{
S. K. Auntu and F. Nusrat
}

\section{ABSTRACT}

\begin{abstract}
Stagnation in terrorism research is held responsible to both academicians and the government for exploring the continuity of terrorist activities in Bangladesh. The state of stagnation, in this regard, is mainly linked with the governmental strategy of funding research though government is not willing to share their information with academia; on the other hand, little empirical grounding in academia. In spite of having methodological skills there are lacks of data is the behind of sloth condition in this sector. A developing country like Bangladesh is a prominent example of this stagnation in terrorism research and has experienced several violent activities on the time being. Sometimes, ISIS has claimed their existence in several attacks in Bangladesh, but, still, the recruitment and training up process in violent radicalization that motivates different terrorist activities are still beyond control. This paper will explore the existence of stagnation in terrorism research and how it explores the continuity of terrorist activities in Bangladesh. Finally, in conclusion, this paper will give some recommendations to bridge the existing gap between the academicians and the government to terminate the stagnation in terrorism, particularly in the context of Bangladesh.
\end{abstract}

Keywords: Bangladesh, Continuity, Explore, Stagnation, Terrorism.
Published Online: November 12, 2021

ISSN: $2736-5522$

DOI: $10.24018 /$ ejsocial.2021.1.6.169

\section{S. K. Auntu*}

Department of International Relations, Bangladesh University of Professionals, Bangladesh.

(e-mail: sumaya.bupir17@gmail.com) F. Nusrat

Department of International Relations, Bangladesh University of Professionals, Bangladesh.

(e-mail: fariabup21@gmail.com)

*Corresponding Author

\section{INTRODUCTION}

Despite over a decade, many researchers have been working on terrorism, but still one question is unknown that what things lead an individual to join terrorist activities (Parvez, 2016). Many of the old scholars tried to address the question with their assumption that they were involved with terrorist activities or political violence because of their personal grievances. After the $9 / 11$ incident, it is no longer served and brought a new emergency again to raise the question of how individuals turn to political violence or terrorist activities. Finally, researchers found that terrorist activities are not only personal reasons, but it also has other reasons (Janbek \& Williams, 2014).

Many scholars claim that there has been a gap between academia and the intelligence community (Parvez, 2016). The reason behind it is that the government is not willing to share their information related to terrorist activities with academia that led to state stagnation in this sector. In spite of having rich methodological skills, there is a lack of data that made scholars indifferent to research regarding terrorist activities and led to an explosion of speculations. Bangladesh is the most prominent secular democracy, but Bangladesh has experienced a lot of violence activities by Islamic extremists since 2000 (Lorch, 2020). Even In 2017, ISIS claimed responsibility for three attacks in Bangladesh (Lorch, 2020). As a result, in recent times, many Bangladesh researchers are working on expositing the determinants of popular support of Islamist terrorism (Parvez, 2016).

\section{A. Research Purpose}

The purpose of this research paper is to find out whatever the stagnation in terrorism research is a reality or not in the context of Bangladesh. The paper will also explore how the stagnation in terrorism research explores the continuity of terrorist activities in Bangladesh. Finally, this paper will provide recommendations to bridge the gap between academicians and the government.

\section{B. Theoretical Framework}

Radicalization refers to believing or supporting the extreme views and the main goal to significant changes in the society that may create conflict or a direct threat to the existing order in particular nations or areas. There is no single explanation of radicalization or single profile of radicals. A limited number of distinct reasons have been identified which take individuals towards radicalism. There is no single socioeconomic profile that can describe the characteristics of radicalized individuals (Horgan, 2008).

It is quite difficult to determine individual sets of motivation at individual levels of radicalization. The gap between knowledge and data is held responsible for exploring the terrorist motivations as well as 
activities at individual level, claimed by the sociologists. According to social movement theory and network theory, sometimes social networks among friends and peer groups work as a medium of spreading the motivation of radicalization. These groups of people generate a set of beliefs that the origin of injustice lies in the existing order that needs to be changed (Bhui et al., 2012).

Different profiles possess different reasons and backgrounds for being attracted to radicalization. But lack of data binds the hand of the scholars or academicians to theorize the radicalization process; on the other hand, the government is less likely to be successful with the plenty of data to tackle radicalization in the absence of proper theoretical knowledge (Fabe, 2017).

\section{Research Question}

The research question has been followed in this research paper as below.

How does the stagnation in terrorism research explore the continuity of terrorist activities in Bangladesh?

\section{Limitation of the Study}

Due to the Covid-19 pandemic, on ground data collection was not possible. Although several secondary data have been analyzed, but, stagnation in terrorism research mainly generates the lack of information regarding the process of radicalization, training up, their activities and finally promote the failure to theorize the entire procedures and countermeasures in Bangladesh.

\section{REVIEW OF LITERATURE}

The article name "Bombs and Ballots: Terrorism, Political Violence, and Governance in Bangladesh" by Naureen Chowdhury Fink expressed that though the Bangladesh government takes initiatives to counter, but still, terrorim creates a significant level of threats and challenges. Finally, he proposed that government and citizens must strengthen their relations for countering terrorism (Fink, 2010).

The article named "The Funding Methods of Bangladeshi Terrorist Groups" by Paul Cochrane described how terrorist groups of Bangladesh arranged their Finance system through different neighboring states like Myanmar (Cochrane, 2009).

The article named "Islamic state ideology continues to resonate in Bangladesh" by Iftekharul Basar explained the efforts of the Bangladesh security forces to counter extremism. He emphasizes social awareness in this regard, and emphasizes societal awareness after the Holey Artisan Café attack 2016 (Bashar, 2019).

The article name "News Analysis - Sholakia attack: The last major terror incident in Bangladesh" by M Abul Kalam Azad explained Harkat-ul Jihad al-Islami Bangladesh (HuJI-B) and Jamaatul Mujahideen Bangladesh (JMB), both adherents of Al-Qaeda's thought and believe, carried out numerous bombing and grenade attacks from 1999 to 2005, killing hundreds. The two radical Islamist groups attacked in The Sholakia during Eid day in 2016 linked to Al-Qaeda and IS. Finally, Azad found that Bangladesh has been successful in tackling extremism largely through forces (Azad, 2021; Khan, 2017).

The article name "Profiles of Islamist Militants in Bangladesh by Shafi Md Mostofa and Natalie J. Doyle" explained that online radicalization is playing a larger role, and militant organizations are increasingly recruiting urban youths attending secular educational institutions, from both the upper and the middle classes (Mostofa \& Doyle, 2019).

\section{Methodology}

In this paper, qualitative research methodology has been followed based on secondary data (Woods, 2005). Different books, journals, news articles, websites had been used to develop the paper, but according to the main concern focused in this paper, very little practical evidence has been found to determine the key motivation of terrorism (Islam, 2008; Mannan, 2019).

\section{DISCUSSION}

Terrorism research is, by nature, multidisciplinary, which means that it will gather many brilliant scholars from different sectors. They usually work with an informative set of data. But, the fragmented nature of funding and a lack of reliable comprehensive data have brought terrorism research to a state of stagnation (Sageman, 2014). As a result, there has been a blast of theories with little empirical data in academia. In spite of having methodological skills, there are lacks data is the behind of sloth condition in this sector The way the understanding or realization of stagnation in terrorism research assist the development of remedial measures will be represented below from Bangladesh perspective (Kumar \& Naser, 2010; Naser \& Sriwas, 2008). 
Following the 9/11 attacks, there was an influx of newcomers into the field of terrorism research. Laymen who controlled funding and prioritized it based on their questions dominated the field, as did media experts who conducted their own "research" (Janbek \& Williams, 2014). These "experts" continue to dominate the airwaves and without hesitation give their opinions to journalists, framing terrorist events for the general public (Datta, 2007); they can openly witness many military operations and, on occasion, get a rare opportunity to interview them (Fair, 2018). One critical point is that academicians do not follow the same procedures as journalists in these operations, and as a result, they receive negative feedback. They face some difficulties, such as determining what they will expose, how they will expose it, and whether or not they have any substantial evidence (Gohel, 2014). Academicians take their time developing an idea, whereas journalists simply complete their tasks without questioning them. They only aim to pursue a political agenda (Rahman, 2016). Despite the lack of training to recognize or analyze trends, they do enjoy making sensational statements to run their business. It creates a gap between the academicians and the policymakers, which has been termed as stagnation (Fair et al., 2017). The initial federal funding for terrorism research identified the Holy Quran's sole guidance explained in a wrong way to the young generation that transforming young people into extremists (Sageman, 2014). In the case of the attack on the Holey Artisan Bakery, Prime Minister Sheikh Hasina was convinced that the attackers were homegrown Jihadis. Though the intelligence community had claimed that they had information, it was ultimately the intelligence failure (Kumar \& Naser, 2010; Naser \& Sriwas, 2008). Information Minister Hasanul Huq Inu disclosed that Pakistan's all-powerful Inter-Services Intelligence (ISI) had trained up 8000 Bangladeshi Jihadis (Datta, 2007). At first, they had targeted Mumbai, next Dhaka. He suspects that they are planning to take revenge for the liberation war, 1971 (Fair, 2018). According to the NSI officials, six batches of Bangladeshis were trained in CHT and then sent to Pakistan (Gohel, 2014). They had this information but if they could share it with the academicians, perhaps through the combined efforts of methodological approach with comprehensive data which could avoid this disaster (Rahman, 2016). In response to this situation, some academics or scholars of political Islam may have been able to change their minds. This, however, is not possible due to the current state of stagnation (Fair et al., 2017).

Terrorist organizations nowadays have designed their plans in such a way that they are difficult to track in the current context (Sageman, 2014). For example, one boy in Gazipur District grouped with three other boys. But due to their ten months of terrorist training, their operational and communication skills had developed in such a way that in spite of catching one of them, the security forces had failed to trace the other three (Kumar \& Naser, 2010; Naser \& Sriwas, 2008). Consequently, relying solely on National Laboratories and computer scientists will not suffice, since, unfortunately, for various reasons, many scholars rely on either journalistic investigation or government officials' political statements directed at a specific audience (Datta, 2007). Whereas academicians are exchanging their insights from other disciplines to terrorism research is another way to extrapolate from other fields. Some people think of terrorists as psychopaths (people who lack empathy), criminals, gang or cult members, or mobsters (Fair, 2018).

It is difficult for academics to research a peaceful environment where they feel free to find information that will help the government change its policy as well (Gohel, 2014). Since, a policy cycle needs agenda setting, policy formulation, policy adoption, implementation and evaluation. It is a lengthy process where the cooperation of all the stakeholders is highly required (Rahman, 2016).

It is not always mandatory that the terrorist attack should be conducted by young people or the Jihadis. After the Atia Mahal experience, security forces who had conducted the operation exclaimed that the militants of Bangladesh are capable enough for manufacturing bombs. It is a matter of concern for the future safety and security of Bangladesh (Fair et al., 2017). To deal with the situation, detailed evidence with reliable data must be shared with the academicians so that after conducting in depth research, they can recommend necessary policies to overcome these situations in the long term. This requires political bravery and determination as well (Sageman, 2014).

It is not the issue that the terrorism research on ground is not conducted in Bangladesh. Focusing on the Journalist Mohsin- ul- Hakim's Story, it was his efforts to convince the pirates to surrender (Kumar \& Naser, 2010; Naser \& Sriwas, 2008). He had to work very hard to make them surrender peacefully with the hope of a secure future (Datta, 2007). It had been taking seven years and during this period, he had to stay at that place, collect empirical data and work on that at random (Fair, 2018). It was not possible for him as an armchair investigator. In the present context, many scholars have completed their Ph.D. on Chittagong Hill Tracts (CHT) (Gohel, 2014). The world is changing and proceeding towards advancement. Keeping pace with the changing world, the existing terrorism research system must be changed by ensuring productive interactions between the two communities (Rahman, 2016). 


\section{CONCLUSION}

The government of Bangladesh usually is found to adopt reactive measures rather than prevention. Alongside, failure to determine the root causes of radicalization and procedures of the terrorist attack are recognized as a result of stagnation in terrorism research in Bangladesh.

Since the government does not share any information regarding different violent extremism, radicalization, or different types of terrorist activities as well as designated organizations, that holds back the academicians to recommend any tactful solutions through proper theorization. As a result, it does not bring any long-term solution to this problem. After the incidents of 9/11, most of the countries are found to use their military forces for counterterrorism. But unfortunately, it resulted in reverse where the terrorist groups have become more violent. The counterterrorism activities in Bangladesh still fail to represent a broader national imperative.

Finally, Bangladesh Government should co-operate with the new ideas regarding terrorism offered by the academicians. Besides, they should patronize the young researchers who are working in this field through financial assistance or providing data or through training. The media and terrorist groups have symbiotic relations, so the government needs to be more focused on this side too.

\section{RECOMMENDATIONS}

1. The stagnation of this field could be reduced if the government, researchers, and politicians keep communication among them by sharing data. That means the field has stagnated due to the lack of communication and data sharing among them. So, they have to work together.

2. Government should provide financial support to researchers to do more research in this field.

3. Researchers should be more focused on the Family of terrorist groups so that society should not marginalize them from society.

4. Finally, this field is very vast because the type of terrorist activities rapidly changes. So it should be more patience doing research in this field.

\section{FUNDING}

No financial support was received for the publication of this work.

\section{CONFLICT OF INTEREST}

The authors declare no conflict of interest.

\section{REFERENCES}

Azad, M. A. K.( 2021). News Analysis - Sholakia attack: The last major terror incident in Bangladesh. Dhaka Tribune, Bangladesh, July, 7.

Bashar, I. (2019). Islamic State Ideology Continues to Resonate in Bangladesh. Middle East Institute, 3.

Bhui, K. S., Hicks, M. H., Lashley, M., \& Jones, E. (2012). A public health approach to understanding and preventing violent radicalization. BMC medicine, $10(1), 1-8$.

Cochrane, P. (2009). The funding methods of Bangladeshi terrorist groups. Combating Terrorism Centre, 2.

Datta, S. (2007). Islamic militancy in Bangladesh: The threat from within. South Asia: Journal of South Asian Studies, 30(1), 145170 .

Fabe, A. P. H. (2017). Countering terrorism in Bangladesh. In The Palgrave handbook of global counterterrorism policy (pp. 621634). Palgrave Macmillan, London.

Fair, C. C. (2018). Political Islam and Islamist Terrorism in Bangladesh: What You Need to Know. Lawfare, January, 28.

Fair, C. C., Hamza, A., \& Heller, R. (2017). Who supports suicide terrorism in Bangladesh? What the data say. Politics and Religion, 10(3), 622-661.

Fink, N. C. (2010). Bombs and ballots: Terrorism, political violence, and governance in Bangladesh. International Peace Institute (IPI).

Gohel, S. M. (2014). Bangladesh: An emerging centre for terrorism in Asia. Perspectives on Terrorism, 8(3), 84-91.

Horgan, J. (2008). From profiles to pathways and roots to routes: Perspectives from psychology on radicalization into terrorism. The ANNALS of the American Academy of Political and Social Science, 618(1), 80-94.

Islam, M. A. (2008). Mapping terrorism threats in Bangladesh. BIISS journal, 29(2), 153-176.

Janbek, D., \& Williams, V. (2014). The role of the internet post-9/11 in terrorism and counterterrorism. The Brown Journal of World Affairs, 20(2), 297-308.

Khan, S. E. (2017). Bangladesh: The changing dynamics of violent extremism and the response of the state. Small Wars \& Insurgencies, 28(1), 191-217.

Kumar, S. S., \& Naser, M. M. (2010). Understanding suicide terrorism in Bangladesh and Sri Lanka. Regional Centre for Strategic Studies.

Lorch, J. (2020). Terrorism in Bangladesh: Understanding a complex phenomenon. Asian Survey, 60(4), 778-802.

Mannan, M. A. (2019). Bangladesh-China relations: Mapping geopolitical and security interests. Bangladesh-East Asia relations: Changing scenarios and evolving linkages, 81-118.

Mostofa, S. M., \& Doyle, N. J. (2019). Profiles of islamist militants in Bangladesh. Perspectives on Terrorism, 13(5), $112-129$. 
Naser, M., \& Sriwas, S. K. (2008). Understanding Suicide Terrorism in Bangladesh and Sri Lanka. SY Surendra Kumar and Mostafa Mahmud Naser, Understanding Suicide Terrorism in Bangladesh and Sri Lanka,(Regional Centre for Strategic Studies (RCSS) Sri Lanka, 2010).

Parvez, S. (2016). Terrorism and Counter-terrorism in Bangladesh. In Riaz, A., \& Rahman, M. S. (Eds.), Routledge Handbook of Contemporary Bangladesh ( $1^{\text {st }}$ ed., pp. 425-437). Routledge.

Rahman, M. A. (2016). The Forms and Ecologies of Islamist militancy and terrorism in Bangladesh. Journal for Deradicalization, 7 , 68-106.

Sageman, M. (2014). The stagnation in terrorism research. Terrorism and political violence, 26(4), 565-580.

Woods, P. (2005). Successful writing for qualitative researchers. Routledge.

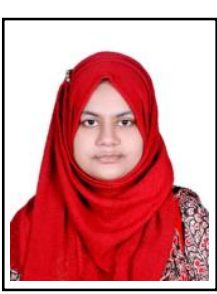

are included here.

- Aktar, R., Siddika, S., Auntu, S. K., Rahman, M. M., \& Adnan, A. T. M. (2021). Impacts of Covid-19 Pandemic on RMG Sector: A Study of Bangladesh. International Journal of Science and Business, 5(11), 1-11.

- Promee, A. T., Auntu, S. K., Sharmin, A., \& Ayon, A. C. (2021). Exploring Traditional Handloom Value Chain and Its Sustainability Constraints in Bangladesh: A Qualitative Study on Tangail Handloom Industries. BUFT Journal of Business \& Economics (BJBE), 2, 252-264.

- Auntu, S. K. (2021). Exploring Globalization on the Perspective of Female Tea Garden Workers of Bangladesh. European Journal of Business and Management Research, 6(2), 176-180.

- Auntu, S. K., Nusrat, F., \& Siddika, S. (2021). Local Integration of the South Sudanese Refugee: Exploring Impact on the Neighboring States. International Journal of Science and Business, 5(5), 120-127.

- Auntu, S. K., \& Promee, A. T. (2020). Repatriation as a Solution of Afghan Refugee Crisis: A Critical Overview. European Journal of Business and Management Research, 5(6), 1-4.

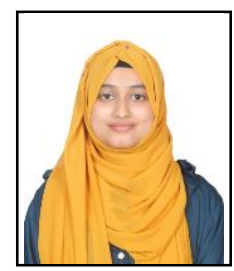

Faria Nusrat was born in Chattogram on 21 February 1998. Currently, she is pursuing her Masters of Social Sciences (MSS) in International Relations at Bangladesh University of Professionals, Dhaka, Bangladesh. Her preferable areas of interest are Refugee Studies, Peace and Conflict Studies, International Development, UN Peacekeeping Operations, Terrorism and Public Policy. The work she has represented here is related to the stagnation of terrorism research in Bangladesh.

She has published several articles in international peer-reviewed journals. Some of the previous publications are included here:

- Auntu, S. K., Nusrat, F., \& Siddika, S. (2021). Local Integration of the South Sudanese Refugee: Exploring Impact on the Neighboring States. International Journal of Science and Business, 5(5), 120 127. 